\title{
Late Pleistocene to Holocene environmental changes as recorded in the sulfur geochemistry of coastal plain sediments, southwestern Taiwan
}

\author{
Yue-Gau Chen ${ }^{\mathrm{a}, *}$, Jack C.L. Liu ${ }^{\mathrm{b}}$, Yuch-Ning Shieh ${ }^{\mathrm{c}}$, Tsung-Kwei Liu ${ }^{\mathrm{a}}$ \\ ${ }^{a}$ Department of Geosciences, National Taiwan University, No. 1, Sec. 4th, Roosevelt Rd, Taipei 106, Taiwan, ROC \\ ${ }^{\mathrm{b}}$ Illinois State Geological Survey, Champaign, IL 61820-6964, USA \\ ${ }^{\mathrm{c}}$ Department of Earth and Atmospheric Science, Purdue University, West Lafayette, IN 47906-1397, USA
}

Received 25 January 2001; revised 29 August 2003; accepted 24 October 2003

\begin{abstract}
A core, drilled at San-liao-wan in the southwestern coastal plain of Taiwan, has been analyzed for total sulfur contents, isotopic values, as well as ratios of pyritic sulfur to organic carbon. Our results demonstrate a close relationship between late Pleistocene sea-level change and the proxies generated in this study. The inorganic sulfur contents indicate that at our study site, the Holocene transgression started at $\sim 11 \mathrm{ka}$ and remained under seawater for thousands of years until the late Holocene, corresponding to a depth of $20 \mathrm{~m}$ in the study core. The uppermost $20 \mathrm{~m}$ of core shows relatively high total organic carbon (TOC) and $\delta^{34} \mathrm{~S}$ of inorganic sulfur, suggesting a transitional environment such as muddy lagoon or marsh, before the site turned into a modern coastal plain. In the lower part of the core, at depths of $110-145 \mathrm{~m}$ (corresponding ages of $\sim 12-30 \mathrm{ka}$ ), low sulfur contents are recorded, probably indicating fluvial sediments deposited during the oceanic isotope stage (OIS) 2, a sea-level lowstand. The lower part of the core, roughly within OIS 3, records at least two transgressions, although the transgressional signals may be somewhat obscured by subsequent weathering. The reworked origin of organic matter reported in previous studies is confirmed by our organic sulfur data; however, the marine organic source was periodically dominant. The modern high sulfate concentrations in pore water have no correlation to the other sulfur species in the sediments, probably indicating that the sulfate migrated into the site subsequent to early diagenesis.
\end{abstract}

(C) 2003 Elsevier Ltd. All rights reserved.

Keywords: Sulfur; Isotope; Late Pleistocene; Sea-level; Organic carbon

\section{Introduction}

Sulfur is ubiquitously distributed in coastal environments where abundant organic matter is trapped, thus facilitating the bacterial reduction of oxidized sulfur species (Peterson and Fry, 1987; Howarth and Giblin, 1983; Bates et al., 1993, 1995). More specifically, the originally mobile sulfate in water can be reduced to hydrogen sulfide via sulfate reducing bacteria (Goldhaber and Kaplan, 1974; Howarth and Giblin, 1983). The hydrogen sulfide is also mobile unless it reacts with reactive iron and ultimately precipitates as pyrite (Berner, 1970, 1984; Howarth, 1979; Bosen and Postma, 1988; Canfield et al., 1992; Lyons and Berner, 1992; Zaback et al., 1993; Morse and Wang, 1997; Raiswell and

\footnotetext{
* Corresponding author. Tel.: +886-2-2369-7648; fax: +886-2-23636095.

E-mail address: ygchen@ccms.ntu.edu.tw (Y.-G. Chen).
}

Canfield, 1998). Sulfate and reactive iron concentrations, as well as organic matter availability, are the general controlling factors for this reaction (Goldhaber and Kaplan, 1975; Berner, 1984; Morse and Cornwell, 1987; Canfield and Berner, 1987; LaLonde et al., 1987; Canfield et al., 1992; Raiswell et al., 1994; Raiswell and Canfield, 1996, 1998). According to a previous study, iron is readily available in both solid and aqueous phases at our study site (Chen, 1996) and thus does not limit pyrite formation. Sulfate concentration and organic matter availability, therefore, are the two dominant controlling factors. Environmental changes, such as sea-level fluctuations, crustal movement and sediment supply can influence these two factors. Consequently, pyrite concentrations or ratios of organic carbon to pyritic sulfur (i.e. $\mathrm{S}_{\mathrm{py}} / \mathrm{TOC}$ ) can be employed as environmental indicators for discriminating marine and terrestrial depositional settings (Berner, 1970, 1982, 1984; Berner and Raiswell, 1984; Morse and 
Berner, 1995; Leventhal, 1995). For $\mathrm{S}_{\mathrm{py}} / \mathrm{TOC}$ ratios, a range of $0.5-0.28$ or a general mean of 0.36 are widely used to represent normal marine deposits.

Bacterial sulfate reduction also induces a large fractionation between the reactant and product, i.e. sulfate and hydrogen sulfide, respectively. Previous culture studies elucidated that the product is depleted in ${ }^{34} \mathrm{~S}$ by $5-46 \%$ o (Harrison and Thode, 1958; Kaplan and Rittenberg, 1964; Kemp and Thode, 1968; Chambers et al., 1975). In marine sediments, observed sulfide isotopic values are much more depleted, with fractionations up to $70 \%$ (Canfield and Thamdrup, 1994; Canfield and Teske, 1996; Habicht et al., 1998). For instance, the isotopic composition of sulfate for seawater over the past several million years is around $+20 \%$ (relative to CDT; Holser and Kaplan, 1966; Claypool et al., 1980; Rees, 1973), thus the $\delta^{34} \mathrm{~S}$ values of hydrogen sulfide are commonly much less than $0 \%$. Such large differences are easily detected by modern massspectrometry. In particular, in coastal areas where sea-level fluctuated during the late Pleistocene, the isotopic composition of sulfur species may assist in unraveling the history of environmental change. Since the availability of iron is not limiting, the hydrogen sulfide might be preserved in the form of pyrite, a common constituent of marine sedimentary rocks. Pyrite also has little isotopic fractionation relative its parent hydrogen sulfide (Jorgensen, 1979; Price and Shieh, 1979).

Organic sulfur in a marine environment can be generally divided into two portions: (1) primary biosynthetic sulfur derived mainly from dead organism detritus (Vairavamurthy et al., 1994, 1995); and (2) sulfur in organic compounds incorporated secondarily during sulfurization of organic matter (Raiswell et al., 1993; Anderson and Pratt, 1995; Bruchert and Pratt, 1996). At sites of high terrigeneous input, the former is usually assumed to be responsible for the observed ${ }^{34} \mathrm{~S}$ because of the high $\delta{ }^{34} \mathrm{~S}$ sources. The latter forms during early diagenesis by reactions of various unsaturated and functionalized lipids with dissolved sulfides and polysulfides, which are depleted in ${ }^{34} \mathrm{~S}$ as a result of bacterial sulfate reduction (Francois, 1987; Kohnen et al., 1989; Sinninghe Damste et al., 1989; Ferdelman et al., 1991; Mossmann et al., 1991; Wakeham et al., 1995). These reactions occur within $10-15 \mathrm{~cm}$ below the sediment surface and prevail where sulfate and organic matter are both abundant. Although certain published cases show insignificant contributions from diagenesis to the total solid organic sulfur reservoir (Canfield et al., 1998), it is believed to likely affect the abundance and isotopic composition of organic sulfur. However, diagenetic organic-sulfur becomes a minor contributor when reactive organic matter is insufficient. Due to the marine origin of the diagenetic organic sulfur, the total concentration of the organic sulfur could assist not only in diagnosing the sources of organic matter, but also in unraveling the alternating history between marine and non-marine deposition.
The concentration and isotopic compositions of sulfur species in sediments are possible proxies for understanding past environmental conditions. In this study, therefore, we focused on the sulfur contents and corresponding isotopic values for a core drilled in the coastal area of southwestern Taiwan. This coastal plain is situated in a modern foreland basin (Fig. 1) formed by arc-continent collision in eastern Taiwan. The borehole is located $30 \mathrm{~km}$ to the west of a mountain front near a small village, San-liao-wan, which is close to the modern coastline (Fig. 1). The core has a length of ca. $200 \mathrm{~m}$ and, according to age determinations, reflects continuous deposition from $50 \mathrm{ka}$ to present (Liu et al., 1997). Because the original purpose for drilling this core was not for isotope analysis, the pore-water samples were exposed to air for a long period of storage. Since the dissolved hydrogen sulfide is easily oxidized to sulfate, it is impossible to extract the original sulfur species. As a result, we determined concentrations and isotopic values for only the solid phases. Nevertheless, some published chemical data for the pore waters are employed in our discussion (Chen, 1996).

\section{Sampling and analytical method}

Twenty-nine samples were collected with a sampling interval of roughly $10 \mathrm{~m}$, spanning the entire $200 \mathrm{~m}$ of core. We then adopted the diffusion method (Fig. 2; Hsieh and Yang, 1989; Hsieh and Shieh, 1997) to extract the inorganic sulfur species and Eschka fusion (ASTM Annual Book of Standard, 1974) to extract the organic sulfur. Initially, samples $(2-5 \mathrm{~g})$ were treated with hot water to dissolve the precipitation formed in the core box due to oxidation and evaporation after coring. Thereafter, the samples were placed in $250 \mathrm{ml}$ flasks for the inorganic sulfur extraction. We placed a small beaker filled with zinc-acetate solution into each flask and then plugged the flasks with rubber stoppers with dual outlets. For the purpose of expelling oxygen, the flasks were flushed by nitrogen gas for $10 \mathrm{~min}$. The reagents were injected through the inlet to let sulfur-containing phases within sediments transform into hydrogen sulfide. The zincacetate trap within the device was used to extract the hydrogen sulfide as zinc sulfide. For the inorganic sulfur study, the following reagents were used: $7 \mathrm{~N} \mathrm{HCl}, \mathrm{Cr}(\mathrm{II})$, and DMF (Dimethyl-formamide) to extract acid volatile sulfur (AVS), chromium reducible sulfur (i.e. pyritic sulfur; abbreviated as $S_{p y}$ ) and elemental sulfur (ES), respectively. The first step was performed over $12 \mathrm{~h}$; however, $48 \mathrm{~h}$ were needed for each of the next two steps. After completing the above sequential extraction, the residual sediments were rinsed with deionized water and dried in an oven at $70{ }^{\circ} \mathrm{C}$. Finally, the dried inorganicsulfur-free samples were transferred to crucibles and extracted for organic sulfur $\left(\mathrm{S}_{\mathrm{org}}\right)$ by Eschka fusion (ASTM Annual Book of Standard, 1974). For the purpose 


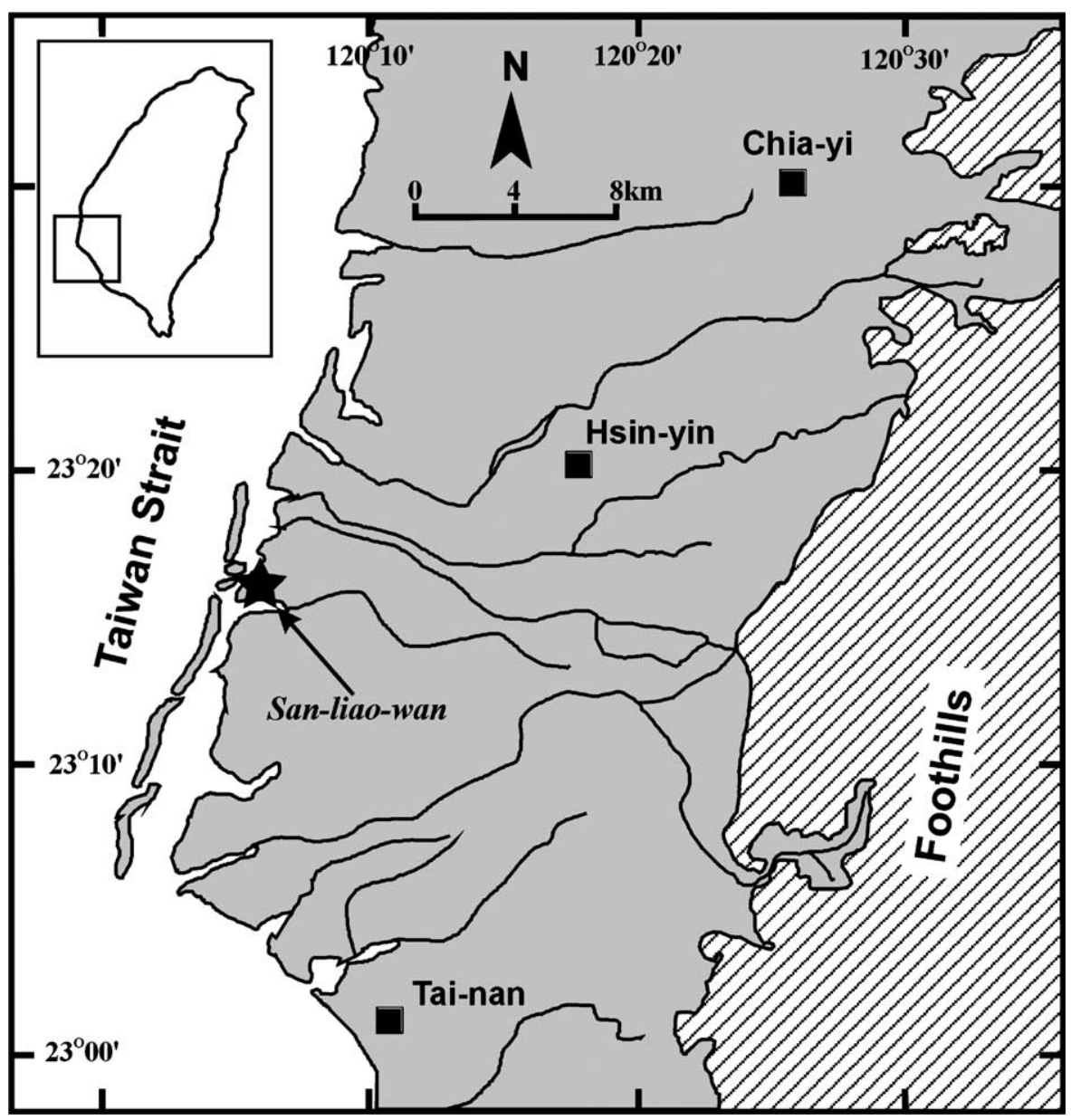

Fig. 1. Map showing the San-liao-wan study site (marked by star) and its neighboring districts. Right area drawn in diagonal lines represents the western foothills of the mountain belt, which formed during the Pengli orogeny, an arc-continent collision. The southwestern coastal plain is recognized as part of the foreland basin.

of complete recovery, we modified the duration and temperatures of the fusion step as follows. The most efficient settings were 100,370 , and $550{ }^{\circ} \mathrm{C}$, respectively, as affirmed by Dr Y. P. Hsieh of Florida A\&M University (personal communication). For each step, the samples were kept in the furnace for more than $24 \mathrm{~h}$. Each sample was analyzed using the entire extraction sequence at least twice. The first round was for concentration determinations. Titration and ion chromatography were used to quantify the concentrations of inorganic and organic species. Analytical precision for concentration is $\pm 5 \%$. In the second round, we reprecipitated the sulfur species as silver sulfide or barium sulfate for isotopic determinations. All the isotopic measurements of the gas samples were carried out at the Illinois Geological Survey, Champaign, USA. The isotopic compositions are expressed relative to the international standard V-CDT and expressed as $\delta^{34} \mathrm{~S}$ with a general error of $\pm 0.2 \%$.

We also measured total organic carbon (TOC). Initially, the freeze-dried samples were decalcified using $1 \mathrm{~N} \mathrm{HCl}$ at $25^{\circ} \mathrm{C}$ overnight. Insoluble residues were then analyzed by combustion in a Leco-SC 444 analyzer. The system precision for this machine is conservatively estimated as $\leqq \pm 5 \%$.

\section{Results}

\subsection{Inorganic and organic sulfur concentrations}

The concentrations for AVS, $\mathrm{S}_{\mathrm{py}}, \mathrm{ES}$, and $\mathrm{S}_{\mathrm{org}}$ are presented in Table 1 and plotted in Fig. 3 in units of $\mathrm{mg} / \mathrm{g}$, i.e. milligrams of sulfur extracted from one gram of sediment. In general, the inorganic sulfur concentrations are less than $1 \mathrm{mg} / \mathrm{g}(0.1 \mathrm{wt} \%)$. Due to the oxidizing conditions of core storage, AVS was possibly transformed to ES. However, both of AVS and ES are comparatively low relative to the $\mathrm{S}_{\mathrm{py}}$, implying that this alteration will not disturb the entire pattern of inorganic sulfur (Fig. 2). Therefore, variations in the pattern of $S_{p y}$ were assumed to record the evolution of the entire inorganic sulfur system. Samples from sediment depths less than $\sim 110 \mathrm{~m}$ exhibited relatively high $\mathrm{S}_{\mathrm{py}}$ concentrations. Based on age data, the abrupt increase in inorganic sulfur concentration occurred at the beginning of 


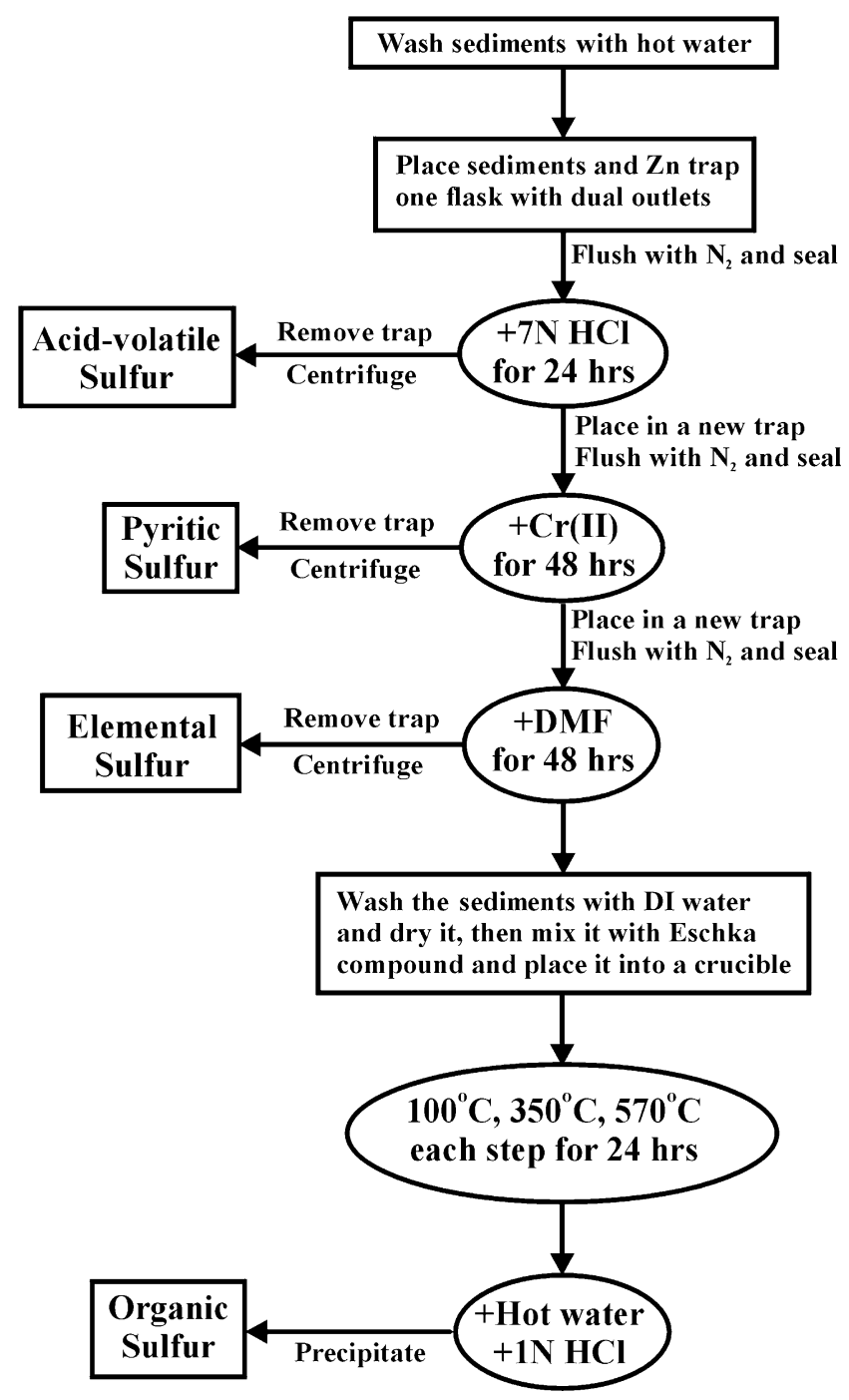

Fig. 2. Flow chart for extracting sulfur species from raw samples. Reagent preparation procedures are based on Canfield et al. (1986), Hsieh and Yang (1989) and Hsieh and Shieh (1997).

oxygen isotope Stage 1 (stratigraphic unit defined by foraminifera $\delta{ }^{18} \mathrm{O}$ in deep sea cores; abbreviated as OIS). These high values generally persisted until the late Holocene. At $90-100 \mathrm{~m}$, ca. $10 \mathrm{ka}$, the values reach a maximum of ca. $1 \mathrm{mg} / \mathrm{g}$. Another peak is found at a depth of $20 \mathrm{~m}$. Most of the samples collected from depths below $110 \mathrm{~m}$ show quite low inorganic sulfur concentrations. However, there are three anomalies found at depths of 147, 160, and 190-200 m, where the ages are distributed within OIS 3.

The concentrations of organic sulfur are generally less than $1 \mathrm{mg} / \mathrm{g}$ ( $0.1 \mathrm{wt} \%$; Fig. 4). These values are lower than previously reported values for normal marine sediments (Francois, 1987; Mossmann et al., 1991). However, at depths where the inorganic sulfur showed relatively high values, the organic sulfur content remained comparatively high. At the base of the upper $100 \mathrm{~m}$, organic concentrations were rather consistent but are more varied over the upper $40 \mathrm{~m}$. These characteristics were also found in the lower part of the core, i.e. from depths of $100 \mathrm{~m}$ to the bottom.

\subsection{Isotope values}

The $\delta^{34} \mathrm{~S}$ values of $\mathrm{S}_{\mathrm{py}}$ range from +15.2 to $-27.6 \%$ (Table 1). The majority of the data are $<0 \%$, indicating that bacterial sulfate reduction dominated the sulfur system over the last several tens of thousand years. The relatively high values are probably caused by temporally limited sulfate supply. Based on the isotopic results of $\mathrm{S}_{\mathrm{py}}$, the OIS 1 profile can be subdivided into two sections. The lower section, i.e. from depths of $110-60 \mathrm{~m} \mathrm{(ca.} 11-7 \mathrm{ka}$ ) shows relatively consistent isotopic values, while the uppermost $60 \mathrm{~m}$ shows significantly more varied and ${ }^{34} \mathrm{~S}$-depleted values. The profile older than OIS1 could also be subdivided into two sections. For the upper section of OIS2, located at depths from 110 to $145 \mathrm{~m}$, some of the $S_{p y}$ concentrations were insufficient to determine isotopic values. The remaining few available data still show values around $-6 \%$. For the lower section, the isotopic 
Table 1

Sulfur content and isotope results of San-Liao-Wan core

\begin{tabular}{|c|c|c|c|c|c|c|c|c|c|}
\hline $\begin{array}{l}\text { Depth } \\
\text { (m) }\end{array}$ & $\begin{array}{l}\text { AVS content } \\
(\mathrm{mg} / \mathrm{g})\end{array}$ & $\begin{array}{l}\mathrm{S}_{\text {py }} \text { content } \\
(\mathrm{mg} / \mathrm{g})\end{array}$ & $\begin{array}{l}\text { ES content } \\
(\mathrm{mg} / \mathrm{g})\end{array}$ & $\begin{array}{l}\text { Total inorganic } \\
\text { sulfur }(\mathrm{mg} / \mathrm{g})\end{array}$ & $\begin{array}{l}\text { Organic sulfur } \\
(\mathrm{mg} / \mathrm{g})\end{array}$ & $\begin{array}{l}\delta^{34} \mathrm{~S}_{\mathrm{py}} \\
(\% \circ)\end{array}$ & $\begin{array}{l}\delta^{34} \mathrm{~S}_{\mathrm{org}} \\
(\% \circ)\end{array}$ & $\begin{array}{l}\text { Total organic } \\
\text { carbon }(\%)\end{array}$ & $\mathrm{S} / \mathrm{C}$ ratio \\
\hline-0.3 & 0.008 & 0.016 & 0.024 & 0.048 & 0.054 & n.a. & n.a. & 0.305 & 0.02 \\
\hline-4 & 0.014 & 0.524 & 0.024 & 0.562 & 0.562 & -8.3 & 8.5 & 0.511 & 0.11 \\
\hline-11 & 0.012 & 0.626 & 0.027 & 0.665 & 0.210 & -21.1 & 6.5 & 0.538 & 0.12 \\
\hline-16 & & & & & & & & 0.113 & \\
\hline-19 & 0.004 & 0.531 & 0.048 & 0.583 & 0.566 & -10.2 & n.a. & 0.527 & 0.11 \\
\hline-20 & 0.002 & 0.776 & 0.087 & 0.865 & 0.923 & 15.2 & 7.2 & 0.627 & 0.14 \\
\hline-25 & & & & & & & & 0.072 & \\
\hline-26 & 0.004 & 0.581 & 0.022 & 0.607 & 0.780 & -19.4 & n.a. & 0.162 & 0.38 \\
\hline-30 & 0.012 & 0.335 & 0.012 & 0.359 & 0.162 & -14 & 8.5 & 0.219 & 0.16 \\
\hline-35 & & & & & & & & 0.221 & \\
\hline-40 & 0.010 & 0.454 & 0.010 & 0.474 & 0.635 & -12.7 & 7.7 & 0.192 & 0.25 \\
\hline-45 & & & & & & & & 0.121 & \\
\hline-51 & 0.016 & 0.316 & 0.009 & 0.341 & 0.698 & -27.6 & 3.8 & 0.176 & 0.20 \\
\hline-61 & 0.016 & 0.336 & 0.005 & 0.357 & 0.593 & -7.6 & 7.3 & 0.377 & 0.10 \\
\hline-65 & & & & & & & & 0.311 & \\
\hline-70 & 0.001 & 0.445 & 0.017 & 0.463 & 0.787 & -1.8 & 4.6 & 0.478 & 0.10 \\
\hline-75 & & & & & & & & 0.177 & \\
\hline-80 & 0.008 & 0.567 & 0.021 & 0.596 & 0.791 & -3.1 & 7.3 & 0.207 & 0.29 \\
\hline-86 & & & & & & & & 0.344 & \\
\hline-90 & 0.024 & 1.124 & 0.018 & 1.166 & 0.865 & -9.7 & 7.6 & 0.432 & 0.27 \\
\hline-95 & & & & & & & & 0.630 & \\
\hline-101 & 0.041 & 0.784 & 0.026 & 0.851 & 0.661 & 2.5 & 7.9 & 0.131 & 0.65 \\
\hline-105 & & & & & & & & 0.130 & \\
\hline-110 & 0.004 & 0.163 & 0.014 & 0.181 & 0.225 & -5.8 & 8.4 & 0.216 & 0.08 \\
\hline-111 & & & & & & & & 0.525 & \\
\hline-117 & 0.015 & 0.006 & 0.002 & 0.023 & 0.543 & n.a. & 10.0 & 0.436 & 0.01 \\
\hline-120 & 0.009 & 0.026 & 0.067 & 0.102 & 0.509 & n.a. & 8.4 & 0.617 & 0.02 \\
\hline-126 & & & & & & & & 0.129 & \\
\hline-130 & 0.037 & 0.050 & 0.023 & 0.110 & 0.464 & -6.4 & 9.0 & 0.336 & 0.03 \\
\hline-146 & 0.008 & 0.011 & 0.011 & 0.030 & n.a. & n.a. & n.a. & 0.345 & 0.01 \\
\hline-147 & 0.019 & 0.977 & 0.091 & 1.087 & 0.754 & -14 & 3.1 & 0.170 & 0.64 \\
\hline-150 & 0.006 & 0.021 & 0.000 & 0.027 & 0.106 & n.a. & 9.7 & 0.291 & 0.01 \\
\hline-155 & & & & & & & & 0.097 & \\
\hline-160 & 0.008 & 0.375 & 0.016 & 0.399 & 0.749 & -1.8 & 7.2 & 0.184 & 0.22 \\
\hline-165 & & & & & & & & 0.207 & \\
\hline-170 & 0.016 & 0.023 & 0.024 & 0.063 & 0.085 & n.a. & 9.3 & 0.123 & 0.05 \\
\hline-173 & 0.010 & 0.090 & 0.012 & 0.112 & 0.581 & -20.1 & n.a. & 1.168 & 0.02 \\
\hline-175 & & & & & & & & 0.193 & \\
\hline-180 & 0.013 & 0.017 & 0.005 & 0.035 & 0.639 & n.a. & -2.0 & 0.558 & 0.01 \\
\hline-183 & 0.000 & 0.047 & 0.018 & 0.065 & n.a. & 4.4 & n.a. & 0.226 & 0.03 \\
\hline-185 & & & & & & & & 0.245 & \\
\hline-190 & 0.006 & 0.387 & 0.096 & 0.489 & 1.121 & -11.8 & 6.7 & 0.296 & 0.17 \\
\hline-195 & & & & & & & & 0.135 & \\
\hline
\end{tabular}

n.a.: not applicable.

values are distributed between +4.4 and $-20.1 \%$, but some samples contained insufficient $\mathrm{S}_{\mathrm{py}}$ concentrations for isotopic determinations.

The isotopic values of organic sulfur are generally distributed in a much tighter range, i.e. from +6 to $+9 \%$; however, isotope minima are found at depths of 50, 70, 147, and $180 \mathrm{~m}$. The lightest value of $-2 \%$ occurs at the depth of $180 \mathrm{~m}$.

\subsection{TOC and $S_{p y} / T O C$ ratio}

The concentrations of TOC generally remain low, i.e. less than $0.6 \mathrm{wt} \%$, over the length of the core (Fig. 5). Several relatively high TOC values $(>0.5 \mathrm{wt} \%)$ are distributed at depths of $<20, \sim 90,110-120$ and $180 \mathrm{~m}$. The calculated $\mathrm{S}_{\mathrm{py}} / \mathrm{TOC}$ ratios show four maxima where the $\mathrm{S}_{\mathrm{py}} / \mathrm{TOC}$ ratio is over 0.2 (Fig. 6; at depths of 26, 

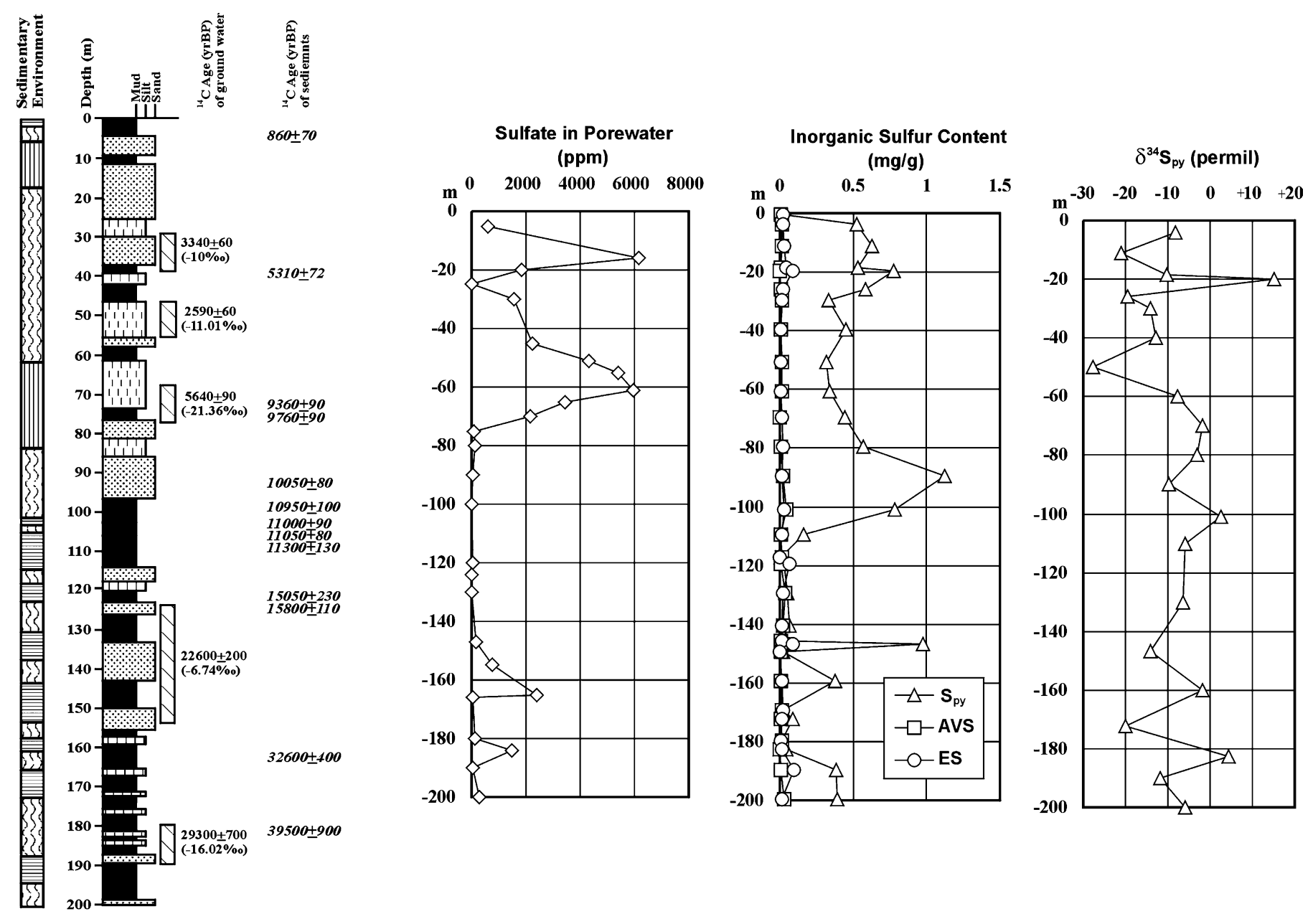

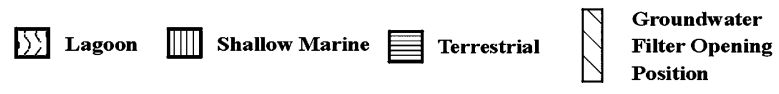

Fig. 3. Inorganic sulfur concentrations and isotopic values of the San-liao-wan core. Comparisons are also made with previous studies, including sulfate concentrations in pore water, age data and sedimentary environment analysis. 

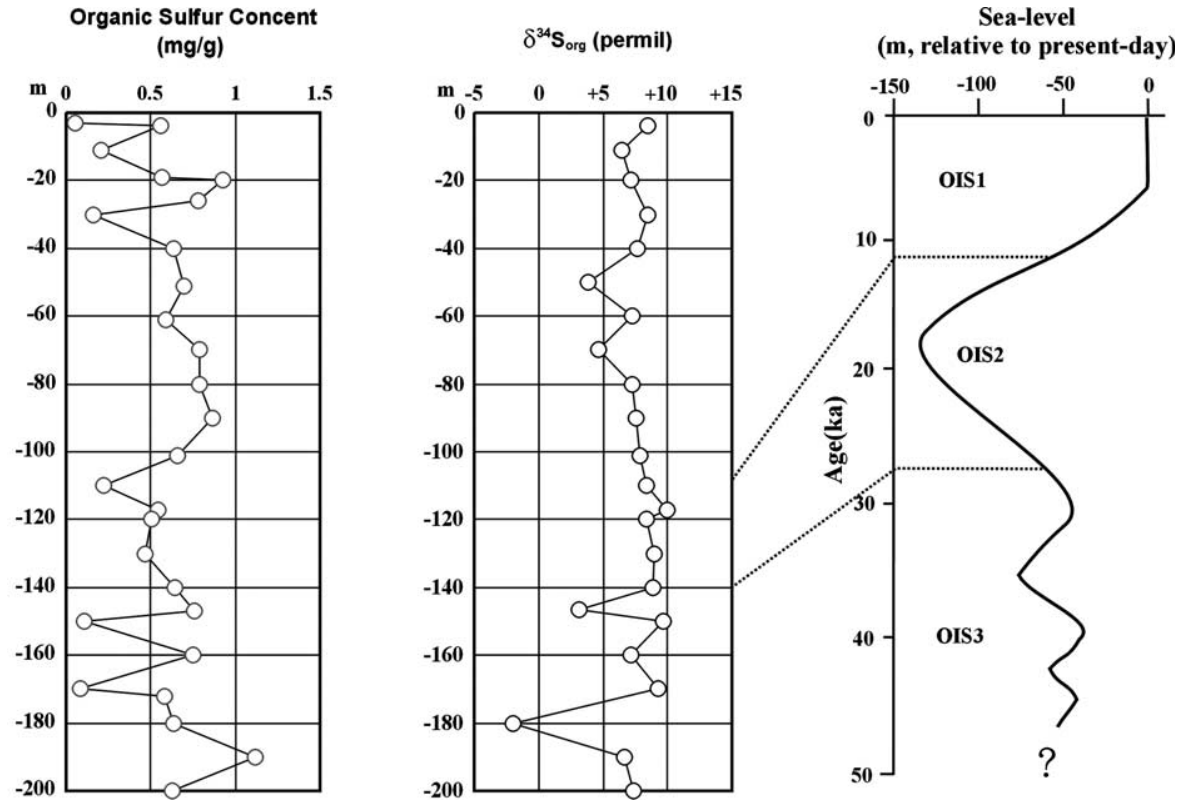

Fig. 4. Organic sulfur concentrations and isotopic values for the San-liao-wan core. The well-known sea-level curve in the corresponding time interval is placed to the right. Oxygen isotope stages determined by foraminifera analysis of deep sea cores are abbreviated as OIS inside.

$80-100,140,147$ and $200 \mathrm{~m}$ ). It is noteworthy that the upper portion of the core (i.e. the top $110 \mathrm{~m}$ ) shows generally higher values than the lower interval.

\section{Discussion}

\subsection{Post-glacial transgression}

Based on the $\mathrm{S}_{\mathrm{py}}$ concentration data, it can be concluded that the post-glacial transgression provided the sulfate that triggered bacterial sulfate reduction and formed $\mathrm{S}_{\mathrm{py}}$ (Fig. 3). The comparatively high $\mathrm{S}_{\mathrm{py}}$ begin at the depth of 100$110 \mathrm{~m}$ (i.e. $\sim 11 \mathrm{ka}$ ), indicating the levels at the onset of the Holocene transgression. The core was used to study the sedimentary facies by counting benthic foraminifers (Lin, 1996, 1998; Sung et al., 1996), which demonstrates that a transgression after last glacial maximum inundated the study area, which was later filled by sediments during the Holocene (as summarized in the far left two columns in Fig. 3). Other studies, including chemical proxies and sequence stratigraphy in neighboring area, also show that the global climatic change governed the local sedimentary history (Hsieh, 1999; Chiang, 2000; Huang, 2001; Ku et al., 2001). Since the environment was coastal, the sulfate supply should not have been a controlling factor on sulfate reduction until it became brackish (Berner, 1984; Westrich and Berner, 1984; Howarth and Teal, 1979). The maxima in $\mathrm{S}_{\mathrm{py}}$ at depths of 90 and $20 \mathrm{~m}$, corresponding to ages of $10 \mathrm{ka}$ and late Holocene, may imply variations in the availability of organic matter. The organic sulfur concentrations also exhibit two maxima at 90 and $20 \mathrm{~m}$ depths, at similar positions to that of $S_{\mathrm{py}}$. This relationship suggests that the diagenetic organic sulfur increased due to abundant dissolved sulfide at that time, which was triggered by the increase in available organic matter. This is confirmed by the corresponding high TOC at the same depths (Fig. 5). As a whole, the sulfur concentration profiles suggest that changes in the sulfur pool at the study site are indeed linked to the post-glacial transgression.

Isotopic values yield additional details regarding environmental changes. Similar to other studies (Jorgensen,

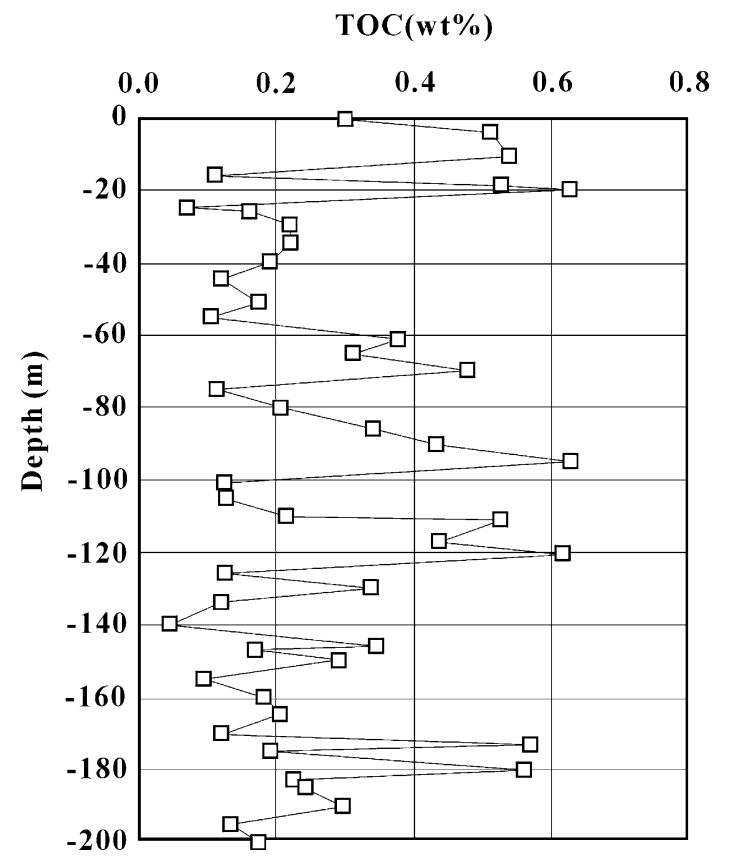

Fig. 5. Total organic carbon (TOC) of the San-liao-wan core, showing that the values are generally lower than $0.7 \mathrm{wt} \%$. Relatively high values are at depths of $<20,60-100,110-120$, and 170-180 m. 


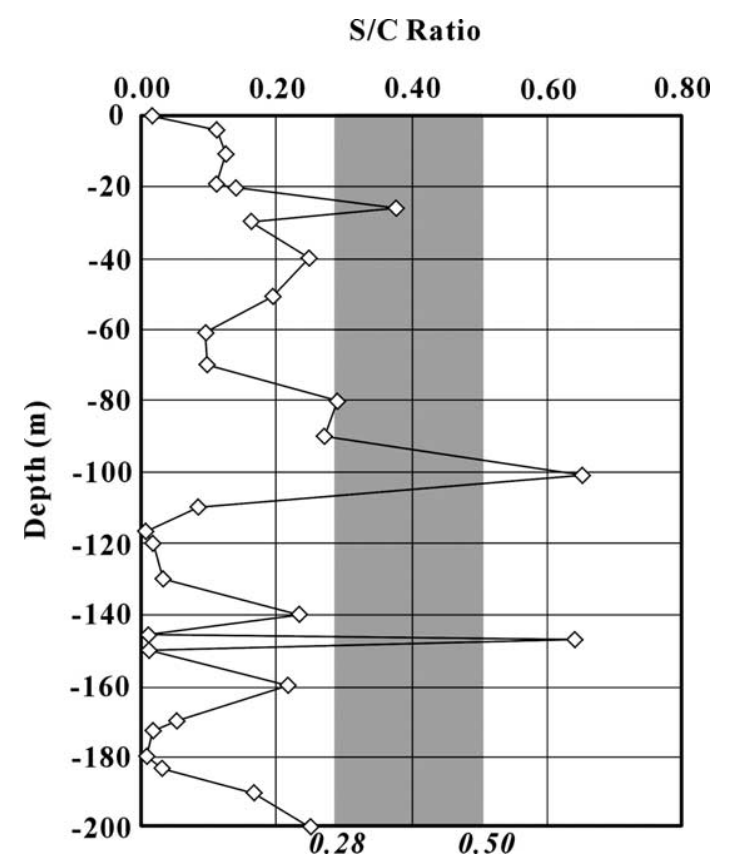

Fig. 6. $\mathrm{S}_{\mathrm{py}} / \mathrm{TOC}$ ratio of the San-liao-wan core. The upper high peaks occur in the Holocene transgression. The relatively high ratios at depths of 140 , 147,160 , and $200 \mathrm{~m}$ may indicate the relict signals in OIS3. Shaded area represents the typical marine values, $0.28-0.50$, previously reported in the literature (Berner, 1970, 1982, 1984; Goldhaber and Kaplan, 1974).

1979; Mossmann et al., 1991), our lower section (i.e. at 110-60 m) with relatively heavier but still negative isotopic values may represent a period with high rates of bacterial sulfate reduction or a lower supply of sulfate. On the other hand, our TOC and $\delta^{34} \mathrm{~S}_{\mathrm{py}}$ results show a positive correlation with heavier isotopic values corresponding to higher TOC (Figs. 3 and 5). It seems that the availability of organic matter controls the isotopic values as reported before (Howarth and Teal, 1979; Berner, 1984; Westrich and Berner, 1984). When available organic matter is high, the sulfate reduction rate must also be relatively high, soon leading to limited ambient sulfate if it is not an open system. Heavier isotopic values of inorganic sulfur will consequently result in this situation. More specifically, it was probably a shallow marine environment experiencing a sealevel rise which led to abundant organic matter inputs of marine origin. This organic matter is considered more reactive toward bacterial degradation than terrigenous organic matter. In the uppermost $60 \mathrm{~m}$, a regression occurred resulting in increased silici-clastics and terrigenous organic matter that diluted the availability of organic carbon. Therefore, the sulfate reduction rate was simultaneously lowered to yield lighter isotopic values of $S_{p y}$. Towards the end of Holocene transgression, the core site likely became shallower resulting in greater input of terrigenous organic matter and fresh water. The sulfate supply may have become limited as the water became fresher. However, sulfate reduction would have occurred, unless the environment completely evolved to a terrestrial environment or the organic reservoir changed (Howarth and
Teal, 1979; Berner, 1984; Westrich and Berner, 1984). Under such conditions, the ${ }^{34} \mathrm{~S}$ was sometimes enriched (i.e. at the depth of $20 \mathrm{~m}$ ).

Based on $\mathrm{S}_{\mathrm{py}} / \mathrm{TOC}$ ratios, we can further confirm that the transgression started at a depth of $110-100 \mathrm{~m}$ and reached a maximum at the depth of 100-80 $\mathrm{m}$ where the ratios are as high as normal marine values (Berner, 1970, 1982, 1984; Goldhaber and Kaplan, 1974; Berner and Raiswell, 1984; Morse and Berner, 1995; Leventhal, 1995; Fig. 6). The corresponding ages are ca. 11 and $10 \mathrm{ka}$, respectively. During the Holocene transgression, TOC contents showed relatively low values as is common in coastal muddy environments (Fig. 5). The relatively high TOC content occurring at the depth of $110-60$ and $<20 \mathrm{~m}$, where a restricted system is indicated by the high isotopic values, might suggest a lagoon or a marsh corresponding to the waning stage of the Holocene transgression.

\subsection{Late Pleistocene sedimentary history}

Based on radiocarbon ages, the zone of low inorganic sulfur at depths of 145-110 m can be correlated to OIS 2 (i.e. 11-27 ka; Morley and Hays, 1981; Fig. 1). During this period, global sea-level was 120-130 m lower than present day (Chappell and Shackleton, 1986), and the study site must have been exposed since the crustal subsidence rate was low (Chen and Liu, 2001). The sulfur source, including inorganic and organic, may have changed from in situ to at least a significant amount of reworked material. The $S_{p y}$ is generally low for the lower part of the study core; however, three relatively high inorganic sulfur intervals at depths of 147,160 , and $190-200 \mathrm{~m}$ are found in the $S_{p y}$ profile (Fig. 3). Low $S_{p y}$ is probably caused by weathering and the lack of sulfate in a subaerial environment. On the other hand, high $S_{\text {py }}$ peaks may indicate that the study site was inundated several times during OIS 3 based on two reliable ages (Fig. 3). Due to the intermittent characteristics, we suggest that this resulted from small-scale sea-level fluctuations analogous to those reported in the literature (Chappell and Shackleton, 1986). However, the absolute sea-level position in OIS 3 is still debated. Also, we lack age control for each sulfur peak. More studies will hopefully clarify this point. In addition, a strongly negative isotopic value for $S_{p y}$ is found at the depth of $173 \mathrm{~m}$ (Fig. 3). This may indicate another transgression, although the corresponding inorganic sulfur concentrations are relatively low. Another isotopic low is identified at the depth of $180 \mathrm{~m}$, which shows a negative value for organic sulfur (Fig. 4) but also a relatively low inorganic sulfur content (Fig. 3). A previous study (Lin, 1996) has reported a few thin paleosols at depths of $100 \mathrm{~m}$ and greater (Fig. 3, the leftmost column). We therefore argue that there were originally high concentrations of inorganic sulfur; however, both peaks have been obscured by subsequent weathering during the later sea-level lowstand. Given this possibility, it is difficult to determine how many transgressions occurred during OIS 
3 at the site. Nevertheless, based on $\mathrm{S}_{\mathrm{py}} / \mathrm{TOC}$ ratios, one transgression at the depth of $147 \mathrm{~m}$ is strongly suggested.

\subsection{Source of organic matter}

Except for depths of 51, 70, 147, and $180 \mathrm{~m}$, the $\delta^{34} \mathrm{~S}_{\mathrm{org}}$ data are distributed within a narrow range from +6.5 to $+10.0 \%$ (Fig. 4). Typically, the isotopic values of organic sulfur covary with the values of inorganic sulfur, if there is enough organic sulfur generated from hydrogen sulfide during diagenesis (Price and Shieh, 1979, 1986; Raiswell et al., 1993; Anderson and Pratt, 1995; Bruchert and Pratt, 1996). Price and Shieh $(1979,1986)$ also reported a close relationship between pyrite and organic sulfur in studies of coal and oil shale (the straight line in Fig. 7). They argued that such a relationship would occur if the organic sulfur is mainly linked to the hydrogen sulfide formed by in situ bacterial sulfate reduction (Fig. 7). Obviously, this is not the case at our site due to the poor relationship between $\delta^{34} \mathrm{~S}_{\mathrm{py}}$ and $\delta{ }^{34} \mathrm{~S}_{\text {org }}$ (Fig. 7), indicating that the organic sulfur pool contained a limited portion generated from hydrogen sulfide during most of the sedimentary history. We therefore suggest that the terrigenous source (i.e. the redeposited organic sulfur) derived from the hinterland may have played an important role. This assertion is supported by a previous study where detrital organic matter from the hinterland constituted a large part of the TOC in the San-liao-wan core (Oung et al., 1997). Nevertheless, our isotopic profile still shows four lighter values, implying that diagenetic sources could dominate. We conclude that an increase in the diagenetic source probably resulted from that transgression, which elevated the sulfate concentration and thus enhanced the bacterial reduction.

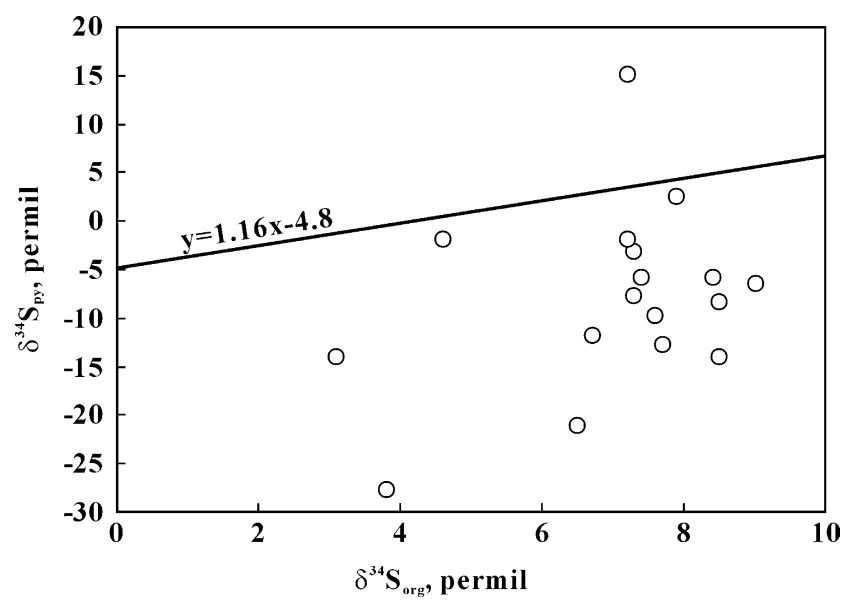

Fig. 7. Open circles are data points of organic sulfur in this study, which show no correlation between isotopic values of $S_{p y}$ and organic sulfur. The solid line is reported in Price and Shieh (1979), indicating that the organic sulfurs of coal and oil shale come mainly from inorganic sulfur. Our results indicate that rather than the inorganic sulfur derived from sulfate reduction, the organic sulfurs in the San-liao-wan core have the other dominant sources, such as the reworked detritus transported from the mountain areas.

\subsection{High sulfate concentrations in pore-water}

In an anoxic marine environment with sufficient organic matter, sulfate will be reduced by bacteria and transformed into hydrogen sulfide. In general, sulfate decreases downward below the sediment-water interface and disappears in the uppermost several tens of centimeters to few meters (Jorgensen, 1979). In some cases, high rates of sulfate reduction commence again at greater depth (i.e. several meters) due to oxidation of methane (Niewohner et al., 1998; Fossing et al., 2000); however, the sulfate concentrations decrease due to bacterial reduction. Beyond that depth, sulfate concentration in pore-water will rapidly approach zero. As shown in Fig. 3, previous pore-water studies demonstrated that the interstitial sulfate is two to three times higher than that of seawater at depths of 10-20 and $\sim 60 \mathrm{~m} \mathrm{(Pi,} \mathrm{1995;} \mathrm{Chen,} \mathrm{1996).} \mathrm{The} \mathrm{concentration}$ profile of sulfate does not correspond well with the inorganic sulfur profile but shows a good correlation with the existing aquifers (i.e. coarse-grained layers). Also, the younger radiocarbon ages of ground water, relative to the depositional ages of the host sediments, implies that water shallower than $100 \mathrm{~m}$ was not original formation water (Fig. 3; Chen, 1996). The high sulfate pore-water might reflect upstream ground water migration into this site after diagenesis.

\subsection{Using sulfur analysis as a proxy for environmental study}

During the past few decades, global change studies have drawn the attention of scientists working on paleoenvironmental change. Many proxies have been identified as powerful tools; however, each one can provide only partial information on the process of environmental change. Sulfur has long been understood as a common constituent in sedimentary rocks and sediments. Sulfur is incorporated into many species, including inorganic and organic phases. Their concentrations and isotopic compositions are strongly influenced by bacterial sulfate reduction and the relevant reactions occurring during early diagenesis. These bacterial reactions require abundant sulfate which is available in marine and coastal environments. Furthermore, the availability of iron and organic matter would influence the pathways and rates of reaction. The best advantage of using sulfur is its accompanied large fractionation of isotopes. As demonstrated in this study, pyrite concentrations and the $\mathrm{S}_{\text {py }} / \mathrm{TOC}$ ratios together delineate where the past transgressive events occurred. In addition, the corresponding isotopic values provide additional information on local conditions. Organic sulfur helps not only in diagnosing the source of organic matter, but also in confirming the results obtained from the pyrite data. As a whole, sulfur data are particularly useful in characterizing paleoenvironments for areas that have alternated between marine and non-marine conditions, such as the southwestern coast of Taiwan. 


\section{Conclusions}

1. The record of Holocene transgression in the study core starts at a depth of 110-100 m, corresponding to an age of ca. $11 \mathrm{ka}$. The accommodation space was gradually filled to create a lagoon or marsh at a depth of $20 \mathrm{~m}$, which recently became subaerially exposed.

2. The sulfur-depleted zone located at core depth of 145$110 \mathrm{~m}$ reflects subaerial exposure during OIS 2.

3. $\mathrm{S}_{\mathrm{py}} / \mathrm{TOC}$ ratios suggest that at least one transgressional signal can be distinguished during the period of OIS 3 . As described in Section 4, the comparatively high concentrations of $\mathrm{S}_{\mathrm{py}}$ and depleted isotopic values suggest one or two more transgressions during OIS 3.

4. The organic sulfur was dominated by non-marine sources, which are mainly composed of reworked organic sulfur eroded from the catchment area. A transgression increased the marine organic source and lowered its associated isotopic values through diagenetic uptake of $\mathrm{S}$.

5. The modern high concentrations of sulfate in pore water are probably the result of subsurface flow subsequent to early diagenesis.

6. The close relationship between the $\delta^{34} \mathrm{~S}_{\text {py }}$ profile and the late Pleistocene sea-level curve confirms that sulfur analysis is useful for unraveling the history of alternating marine and non-marine conditions. In addition, it can further provide detailed information on local paleoenvironments.

\section{Acknowledgements}

We are grateful for valuable comments and suggestions from Dr Timothy Lyons and another anonymous reviewer. We also thank Miss Y.H. Lin, P.L. Wu, and S.F. Huang for their assistance in laboratory work. This paper was supported financially by the National Science Council, ROC under grant no. NSC86-2116-M-002-012.

\section{References}

Anderson, T.F., Pratt, L.M., 1995. Isotopic evidence for the origin of organic sulfur and elemental sulfur in marine sediments. In: Vairavamurthy, M.A., Schoonen, M.A.A. (Eds.), Geochemical Transformations of Sedimentary Sulfur, American Chemical Society, pp. 378-396.

ASTM Annual Book of Standards, 1974. Gaseous Fuels; Coals and Coke; Atmospheric Analysis: Part 26. American Society for Testing and Materials, Philadelphia, 828 pp.

Bates, A.L., Spiker, E.C., Orem, W.H., Burnett, W.C., 1993. Speciation and isotopic composition of sulfur in sediments from Jellyfish Lake, Palau. Chemical Geology 106, 63-76.

Bates, A.L., Spiker, E.C., Hatcher, G.G., Stout, S.A., Weintraub, V.C., 1995. Sulfur geochemistry of organic-rich sediments from Mud Lake, Florida, U.S.A. Chemical Geology 121, 245-262.
Berner, R.A., 1970. Sedimentary pyrite formation. American Journal of Science 268, 1-23.

Berner, R.A., 1982. Burial of organic carbon and pyrite sulfur in the modern ocean: its geochemical and environmental significance. American Journal of Science 282, 451-473.

Berner, R.A., 1984. Sedimentary pyrite formation: an update. Geochimica et Cosmochimica Acta 44, 1955-1965.

Berner, R.A., Raiswell, R., 1984. C/S method for distinguishing freshwater from marine sedimentary rocks. Geology 12, 365-368.

Bosen, C., Postma, D., 1988. Pyrite formation in anoxic environments of the Baltic. American Journal Science 288, 203-575.

Bruchert, V., Pratt, L.M., 1996. Contemporaneous early diagenic formation of organic and inorganic sulfur in estuarine sediments from St. Andrew Bay, Florida, USA. Geochimica et Cosmochimica Acta 60, 2325-2332.

Canfield, D.E., Berner, R.A., 1987. Dissolution and pyritization of magnetite in anoxic marine sediments. Geochimica et Cosmochimica Acta 51, 645-660.

Canfield, D.E., Teske, A., 1996. Late Proterozoic rise in atmospheric oxygen concentration inferred from phylogenetic and sulphur-isotope studies. Nature 382, 127-132.

Canfield, D.E., Thamdrup, B., 1975. The production of 34S-depleted sulfide during bacterial disproportion of elemental sulfur. Science 266, 1973-1975.

Canfield, D.E., Raiswell, R., Westrich, J.T., Reaves, C.M., Berner, R.A., 1986. The use of chromium reduction in the analysis of reduced inorganic sulfur in sediments and shales. Chemical Geology 54, $149-155$.

Canfield, D.E., Raiswell, R., Bottrell, S.H., 1992. The reactivity of sedimentary iron minerals toward sulfide. American Journal of Science 292, 659-683.

Canfield, D.E., Budreau, B.P., Mucci, A., Gundersen, J.K., 1998. The early diagenetic formation of organic sulfur in the sediments of Mangrove Lake, Bermuda. Geochimica et Cosmochimica Acta 62, 761-781.

Chambers, L.A., Trudinger, P.A., Smith, J.W., Burns, M.S., 1975. Fractionation of sulfur isotopes by continuous cultures of Desulfivibrio desulfuricans. Canadian Journal of Microbiology 21, 1602-1607.

Chappell, J.M., Shackleton, N.J., 1986. Oxygen isotopes and sea level. Nature 324, 137-140.

Chen, K.Y., 1996. Geochemistry of pore-water from sediment cores from Zaikung and Sanliaowan, southwestern Taiwan. Master Dissertation. Department of Geology, National Taiwan University, 71 pp (in Chinese).

Chen, Y.G., Liu, T.K., 2001. Holocene uplift and subsidence along an active tectonic margin southwestern Taiwan. Quaternary Science Reviews 19, 923-930.

Chiang, H.W., 2000, Late Pleistocene environment change of coastal plains, western Taiwan: with constraint of the organic carbon isotope compositions. Master Thesis. Department of Geosciences, National Taiwan University, Taipei, Taiwan, ROC, 61 pp.

Claypool, G.E., Holser, W.T., Kaplan, I.R., Sakai, H., Zak, I., 1980. The age curves of sulfur and oxygen isotopes in marine sulfate and their mutual interpretation. Chemical Geology 28, 199-260.

Ferdelman, T., Church, T.M., Luther, G.W. III, 1991. Sulfur enrichment of humic substances in a Delaware salt marsh sediment core. Geochimica et Cosmochimica Acta 55, 979-988.

Fossing, H., Ferdelman, T.G., Berg, P., 2000. Sulfate reduction and methane oxidation in continental margin sediments influenced by irrigation (South-East Atlantic off Namibia). Geochimica et Cosmochimica Acta 64, 897-910.

Francois, R., 1987. A study of sulfur enrichment in the humic fraction of marine sediments during early diagenesis. Geochimica et Cosmochimica Acta 51, 17-27.

Goldhaber, M.B., Kaplan, I.R., 1974. The sulfur cycle. In: Goldberg, E.D., (Ed.), The Sea, vol. 5. Marine Chemistry, Wiley, New York, pp. $569-655$.

Goldhaber, M.B., Kaplan, I.R., 1975. Controls and consequences of sulfate reduction rates in recent marine sediments. Soil Science 119, 42-55. 
Habicht, K.S., Canfield, D.E., Rethmeier, J., 1998. Sulfur isotope fractionation during bacterial reduction and disproportion of thiosulfate and sulfite. Geochimica et Cosmochimica Acta 62, 2585-2595.

Harrison, A.G., Thode, H.G., 1958. Mechanism of the bacterial reduction of sulphate from isotope fractionation studies. Transaction of Faraday Society 54, 84-92.

Holser, W.T., Kaplan, I.R., 1966. Isotope geochemistry of sedimentary sulfates. Chemical Geology 1, 93-135.

Howarth, R.W., 1979. Pyrite: its rapid formation in a salt marsh and its importance in ecosystem metabolism. Science 203, 49-51.

Howarth, R.W., Giblin, A., 1983. Sulfate reduction in the salt marshes at Spelo Island, Georgia. Limnology and Oceanography. 28 (1), 70-82.

Howarth, R.W., Teal, J.M., 1979. Sulfate reduction in a New England salt marsh. Limnology and Oceanography 24, 999-1013.

Hsieh, C.C., 1999. Late Pleistocene environmental changes in San-liao-wan area, southwestern Taiwan: with constraint of organic carbon isotopes of modern and core sediments. Master Thesis. Department of Geosciences, National Taiwan University, Taipei, Taiwan, ROC, 66 pp.

Hsieh, Y.P., Shieh, Y.N., 1997. Analysis of reduced inorganic sulfur by diffusion methods: improved apparatus and evaluation for sulfur isotopic studies. Chemical Geology 137, 255-261.

Hsieh, Y.P., Yang, C.H., 1989. Diffusion methods for the determination of reduced inorganic sulfur species in sediments. Limnology Oceanography $34,1126-1130$.

Huang, Y.T., 2001, Upper Quaternary sedimentary environments and sequence stratigraphy of the Tsengwenhsi River basin, Chianan plain: a preliminary study. Master Thesis. Department of Geosciences, National Taiwan University, $187 \mathrm{pp}$.

Jorgensen, B.B., 1979. A theoretical model of the stable sulfur isotope distribution in marine sediments. Geochimica et Cosmochimica Acta 43, 363-374.

Kaplan, I.R., Rittenberg, S.C., 1964. Microbiological fractionation of sulfur isotopes. Journal of General Microbiology 34, 195-212.

Kemp, A.L.W., Thode, H.G., 1968. The mechanism of the bacterial reduction of sulphate and of sulphite from isotope fractionation. Geochimica et Cosmochimica Acta 32, 71-91.

Kohnen, M.E.T., Sinninghe Damste, J.S., Ten Haven, H.L., de Leeuw, J.W., 1989. Early incorporation of polysulfides in sediment organic matter. Nature 341, 640-641.

Ku, H.W., Chen, Y.G., Hsieh, C.C., Liu, T.K., Liu, J.C.L., 2001. Paleoenvironment study at Yichu, southwestern Taiwan: a case study on geochemical analysis of sulfur and carbon. Western Pacific Earth Sciences 1 (2), 175-186.

LaLonde, R.T., Ferrara, L.M., Hayes, M.P., 1987. Low-temperature, polysulfide reactions of conjugated ene carbonyls: a reaction model for the geologic origin of S-heterocycles. Organic Geochemistry 11, 563-571.

Leventhal, J.S., 1995. Carbon-sulfur plots to show diagenetic and epigenetic sulfidation in sediments. Geochimica et Cosmochimica Acta 59, 1207-1211.

Lin, Y.T., 1996. Environmental analysis of the core sediments in Zeikang and Sunliaowan, Tainan county, Taiwan. Master Dissertation. Department of Earth Sciences, National Chengkung University, Tainan, Taiwan, ROC, 120 pp.

Lin, S.Y., 1998. Depositional environment on the coastal plain in the southwestern Taiwan Taiwan. Master Dissertation. Department of Earth Sciences, National Chengkung University, Tainan, Taiwan, ROC, 124 pp.

Liu, T.K., Chen, K.Y., Sung, Q.C., Yang, C.H., Chen, P.H., 1997. Hydrogeology and vertical variation of groundwater quality in ZeikangSanliaowan area, southwestern Taiwan. Annual Meeting of the Geological Society of China, Abstracts 1997, 538-541.

Lyons, T.W., Berner, R.A., 1992. Carbon-sulfur-iron systematics of the uppermost deep-water sediments of the Black Sea. Chemical Geology $99,1-27$.
Morley, J.J., Hays, J.D., 1981. Towards a high-resolution, global, deep-sea chronology for the last 750,000 years. Earth and Planetary Science Letters 53, 279-295.

Morse, J.W., Berner, R.A., 1995. What determines sedimentary C/S ratios? Geochimica et Cosmochimica Acta 59, 1073-1077.

Morse, J.W., Cornwell, J.C., 1987. Analysis and distribution of iron sulfide minerals in recent anoxic marine sediments. Marine Chemistry 22, $55-69$.

Morse, J.W., Wang, Q., 1997. Pyrite formation under conditions approximating those in anoxic sediments. II. Influence of precursor iron minerals and organic matter. Marine Chemistry 57, 187-193.

Mossmann, J.R., Aplin, A.C., Curtis, C.D., Coleman, M.L., 1991. Geochemistry of inorganic and organic sulphur in organic-rich sediments from the Peru Margin. Geochimica et Cosmochimica Acta $55,3581-3595$.

Niewohner, C., Hensen, C., Kasten, S., Zabel, M., Schulz, H.D., 1998. Deep sulfate reduction completely mediated by anaerobic methane oxidation in sediments of the upwelling area off Namibia. Geochimica et Cosmochimica Acta 62, 455-464

Oung, J.N., Sung, Q.C., Lin, Y.T., Lin, S.Y., Lin, Y.W., 1997. Sedimentary organic matter in the coastal plain southwestern Taiwan. Annual Meeting of Geological Society of China, Taipei, Taiwan, ROC, Abstract, pp. 37-39 (in Chinese).

Peterson, B.J., Fry, B., 1987. Stable isotopes in ecosystem studies. Annual Review of Ecology and Systematics 18, 293-320.

Pi, Z.L., 1995. A preliminary study on the arsenic enrichment of groundwater in Chianan Area, Taiwan. Master Dissertation. Department of Geology, National Taiwan University, 77 pp (in Chinese).

Price, F.T., Shieh, Y.N., 1979. Fractionation of sulfur isotopes during laboratory syntheses of pyrite at low temperatures. Chemical Geology 27, 245-253.

Price, F.T., Shieh, Y.N., 1986. Correlation between the $\delta^{34} \mathrm{~S}$ of pyritic and organic sulfur in coal and oil shale. Chemical Geology (Isotope Geoscience Section) 58, 333-337.

Raiswell, R., Canfield, D.E., 1998. Sources of iron for pyrite formation in marine sediments. American Journal of Science 298, 219-245.

Raiswell, R., Canfield, D.E., 1996. Rates of reaction between silicate iron and dissolved sulfide in Peru margin sediments. Geochimica et Cosmochimica Acta 60, 2777-2787.

Raiswell, R., Bottrell, S.H., Al-Biatty, H.J., Tan, M.M., 1993. The influence of bottom water oxygenation and reactive iron content on sulfur incorporation into bitumens from Jurassic marine shales. American Journal of Science 293, 569-596.

Raiswell, R., Canfield, D.E., Berner, R.A., 1994. A comparison of iron extraction methods for the determination of degree of pyritisation and the recognition of iron-limited pyrite formation. Chemical Geology $111,101-110$.

Rees, C.E., 1973. A steady-state model for sulfur isotope fractionation in bacterial reduction processes. Geochimica et Cosmochimica Acta 37, $1141-1162$

Sinninghe Damste, J.S., Rijpstra, W.I.C., de Leeuw, J.W., Schenck, P.A., 1989. Quenching of labile functionalized lipids by inorganic sulphur species: evidence for the formation of sedimentary organic sulphur compounds at the early stages of diagenesis. Geochimica et Cosmochimica Acta 53, 1443-1455.

Sung, Q.C., Sun, R.S., Lin, Y.T., Liu, T.K., Yang, C.H., Oung, J.N., 1996. Sedimentary environments of the southwestern coastal plain in Taiwan. Proceedings of The Joint Symposium on Taiwan Quaternary VI and on Investigation of Subsurface Geology and Engineering Environment of Taipei Basin, 286-288.

Vairavamurthy, M.A., Zhou, W., Eglinton, T., Manowitz, B., 1994. Sulfonates: a novel class of organic sulfur compounds in marine sediments. Geochimica et Cosmochimica Acta 58, 4681-4687.

Vairavamurthy, M.A., Wang, S., Khandelwal, B., Manowitz, B., Ferdelman, T., Fossing, H., 1995. Sulfur transformations in early diagenetic sediments from the Bay of Conception, off Chile. In: Vairavamurthy, 
M.A., Schoonen, M.A.A. (Eds.), Geochemical Transformations of Sedimentary Sulfur, American Chemical Society, pp. 38-58.

Wakeham, S.G., Sinninghe Damste, J.S., Kohnen, M.E.L., De Leeuw, J.W., 1995. Organic-sulfur compounds formed during early diagenesis in Black Sea sediments. Geochimica et Cosmochimica Acta 59 $521-533$.
Westrich, J.T., Berner, R.A., 1984. The role of sedimentary organic matter in bacterial sulfate reduction: the $G$ model tested. Limnology and Oceanography 29, 236-249.

Zaback, D.A., Pratt, L.M., Hayes, J.M., 1993. Transport and reduction of sulfate and immobilization of sulfide in marine black shales. Geology $21,141-144$. 